DOI: http://dx.doi.org/10.30747/bfgez.66.2016.14

\title{
ODSŁONIĘCIE TABLICY UPAMIĘTNIAJĄCEJ GEN. ELŻBIETĘ ZAWACKĄ W SIERPCU
}

Dnia 10 IX 2016 r., w Liceum Ogólnokształcącym im. mjra Henryka Sucharskiego w Sierpcu została odsłonięta tablica upamiętniająca gen. prof. Elżbietę Zawacką "Zo" - jedyną kobietę wśród 316. cichociemnych, kurierkę i emisariuszkę Komendy Głównej Armii Krajowej do Sztabu Naczelnego Wodza w Londynie, nauczycielkę matematyki w Korespondencyjnym Liceum Ogólnokształcącym w Sierpcu w roku szkolnym 1955/1956, profesor nauk humanistycznych, drugą Polkę w historii Wojska Polskiego awansowaną na stopień generała brygady.

Od wielu miesięcy o przywrócenie Jej pamięci prowadził starania znany sierpecki społecznik (absolwent Liceum) Kazimierz Czermiński, który przywraca pamięci potomnym miejsca, postaci i wydarzenia związane z historią Polski.

Uroczystość rozpoczęła się symbolicznie $\mathrm{w}$ samo południe, ponieważ 73 lata temu w nocy z 9 na 10 IX 1943 r. z Anglii (w Ekipie XXIX, operacja "Neon 4") w towarzystwie Ferdynanda Serafińskiego, ps. Drabina i Bolesława Polańczyka, ps. Kryształ, „Zo” powróciła drogą powietrzną jako "cichociemna” do Kraju po wykonanej misji, jaką powierzył jej Komendant Główny ZWZ-AK. W trakcie lotu samolot został ostrzelany nad Danią - szczęśliwie niecelnie. 
W uroczystościuczestniczyli:PrezesFundacjiGenerałElżbiety Zawackiej - Dorota Zawacka-Wakarecy oraz dokumentalistki: Anna Rojewska i Barbara Rojek, Waldemar Olejniczak - poseł na Sejm RP, Bogdan Misztal - wiceprzewodniczący Rady Powiatu, Juliusz Gorzkoś - wicestarosta sierpecki, Ewa Leszczyńska - zastępca burmistrza Miasta Sierpc, przedstawiciele stowarzyszeń społecznych, sierpeccy regionaliści, uczniowie i nauczyciele Liceum.

Po powitaniu gości przez dyrektor dr Ewę Jancewicz odsłonięcia tablicy dokonali: Kazimierz Czermiński i Dorota Zawacka-Wakarecy w asyście żołnierzy Jednostki Wojskowej z Kazunia. Następnie ksiądz kan. Andrzej Więckowski, dziekan sierpecki, poświęcił tablicę pamiątkową, po czym złożono kwiaty i zapalono znicze.

Na tablicy umieszczono napis:

\section{Generał \\ Elżbieta Zawacka "Zo" 1909-2009 \\ Stużyłam Polsce \\ Najlepiej jak umiałam. \\ Nauczycielka Liceum w latach 1955-56 \\ Sierpc, 10 września 2016}

Wśród zaproszonych gości nie zabrakło również koleżanki z pracy słynnej generał, emerytowanej nauczycielki Liceum Alicji Lemie-Mroczyńskiej, która napisała i przeczytała wiersz na cześć bohaterki. „Dla mnie to była koleżanka z pracy. Nie lubiła, kiedy ją tytułowano. Była ciepła i koleżeńska, wspaniała osoba" - tak wspominała czasy współpracy z panią generał. Poświęciła jej wiersz kończący się słowami:

Cześć Twojej pamięci Elżbieto - Bohaterze!

Będziemy o Tobie pamiętać, przynajmniej ja w to wierzę.

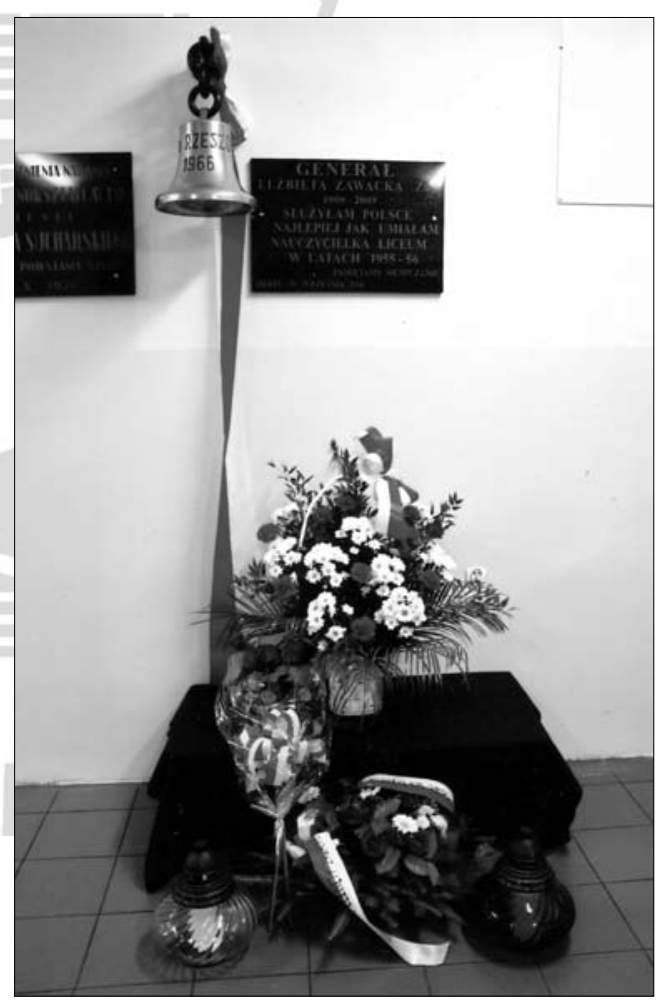

Odsłonięcie tablicy w Sierpcu 
Prezes Fundacji Dorota Zawacka-Wakarecy wyraziła wszystkim zgromadzonym w świetlicy szkolnej, gdzie odbywała się uroczystość, wdzięczność za pamięć o Pani Generał i odczytała list gratulacyjny od Michała Zaleskiego, Prezydenta Miasta Torunia, i Marcina Czyżniewskiego, Przewodniczącego Rady Miasta Torunia. Listy oraz książkę pt. Cichociemna. Generat Elżbieta Zawacka "Zo" (aut. K. Minczykowskiej) prezes Wakarecy wręczyła dyrektor Liceum dr Ewie Jancewicz.

W okolicznościowych wystąpieniach poseł na Sejm RP W. Olejniczak powiedział, że: „Możemy być dziś szczęśliwi i dumni, że w niezwykle bogatej i bohaterskiej biografii Pani Generał przewija się również nasz Sierpc, gdzie po okresie więzienia, licznych upokorzeń, stalinowskich represji i szykan, znalazła w końcu pracę jako nauczycielka".

Na koniec uroczystości odbyły się prezentacja biografii gen. Elżbiety Zawackiej z wykorzystaniem fragmentu filmu pt „Elżbieta Zawacka. Miałam szczęśliwe życie" (reż. M. Widarski), którą przygotowali uczniowie Liceum, oraz wystawa przygotowana przez K. Czermińskiego.

"Przeszłość, która jest w pamięci, zawsze pozostanie teraźniejszością" - posumowała dyrektor Liceum Ewa Jancewicz.

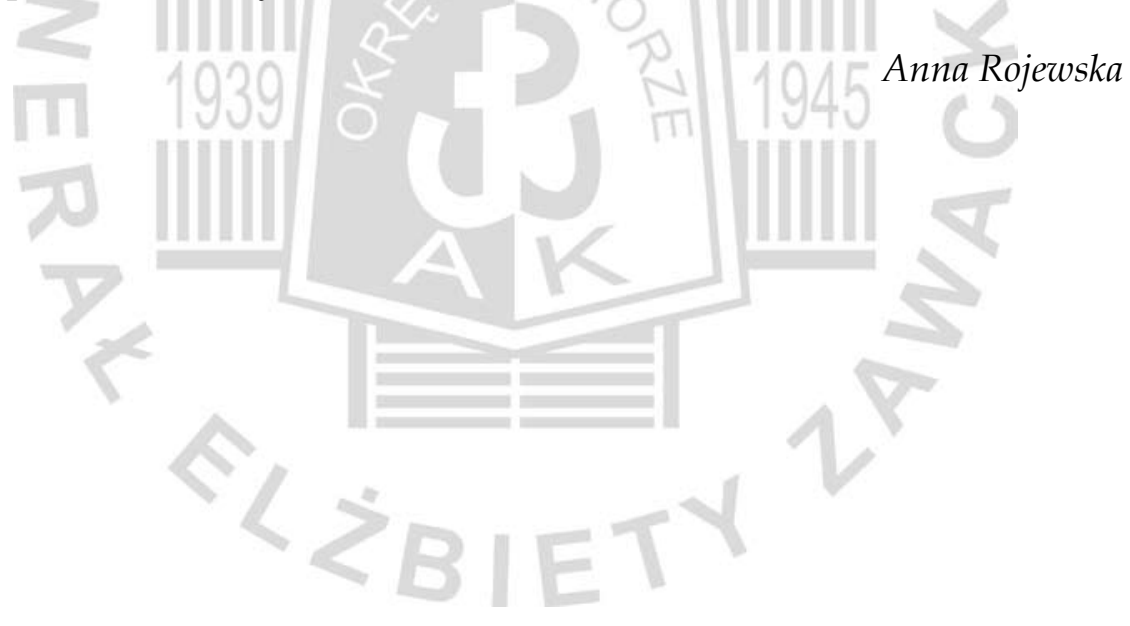

